\title{
A ARTE NA COMPOSIÇÃO METODOLÓGICA DE UMA PESQUISA SOBRE A FORMAÇÃO DOCENTE EM ARTES VISUAIS E BREVES INTENÇÕES PARA A EDUCAÇÃO ESCOLAR EM ARTES VISUAIS NA ATUALIDADE
}

Carmen Lúcia Capra ${ }^{1}$

\section{Resumo}

Trata-se de procedimentos teórico-metodológicos adotados para a constituição da tese "Problematizações sobre políticas da arte na licenciatura em artes visuais. É preciso gostar da arte de outro jeito, a licenciatura é uma praça", realizada no Programa de Pós-graduação de Faculdade de Educação da Universidade Federal do Rio Grande do Sul (UFRGS), e concluída em 2017. A metodologia artística de investigação é apresentada em seus diferentes processos, tendo a arte como experiência e modo de produzir conhecimento na pesquisa em educação. Ao final, são tecidas breves considerações sobre a formação docente em artes visuais em relação ao contexto brasileiro contemporâneo, de desconfiança em relação às artes e à educação. Propõe-se que a reconfiguração da experiência com a arte na formação docente em artes visuais possa contribuir a uma ação política e educativa na escola.

Palavras-chave: Licenciatura. Artes visuais. Educação. Metodologia artística de investigação.

\section{THE ART IN THE METHODOLOGICAL COMPOSITION OF A RESEARCH ON TEACHER TRAINING IN VISUAL ARTS AND BRIEF INTENTIONS FOR SCHOOL EDUCATION IN VISUAL ARTS TODAY}

\begin{abstract}
This text expatiates on the theoretical and methodological proceedings used for writing the thesis "Problematizações sobre políticas da arte na licenciatura em artes visuais. É preciso gostar da arte de outro jeito, a licenciatura é uma praça", fufilled at the Graduate Program of the Faculty of Education (PPGEDU) of the Federal University of Rio Grande do Sul (UFRGS), in 2017. The artistic methodology for investigation is presented in its different processes, placing art as an experience and a knowledge producing model within the education's research. In the long run, some considerations about the visual arts teaching education are made, regarding the contemporary Brazilian context of the suspicion with arts. It is proposed that a reorganization of the experience with art during the visual art teacher's formation can contribute to political and educational activities in the school.
\end{abstract}

Keywords: Licentiate. Visual arts. Education. Artistic methodology for investigation.

\footnotetext{
${ }^{1}$ Doutora em Educação pela Universidade Federal do Rio Grande do Sul. Professora na Universidade Estadual do Rio Grande do Sul - UERGS. Endereço eletrônico: carmen-capra@uergs.edu.br.
}

Criar Educação, Criciúma, v. 7, ㄲo1, jan/jul 2018.- PPGE - UNESC 
Esse texto visa compartilhar itens de uma pesquisa de doutorado que pretendeu estar na arte e na educação, com cada uma e em cada uma. Trata-se da tese "Problematizações sobre políticas da arte na licenciatura em artes visuais. $E$ preciso gostar da arte de outro jeito, a licenciatura é uma praça", realizada no Programa de Pós-graduação de Faculdade de Educação da Universidade Federal do Rio Grande do Sul (UFRGS) no período entre 2013 e 2017, sob orientação de Luciana Gruppelli Loponte, na linha de pesquisa "Arte, Linguagem e Currículo". Tratarei especificamente da metodologia da pesquisa, atendendo ao propósito do "I Seminário de Pesquisa em Arte: contextos híbridos da a/r/tografia e cartografia na produção de saberes em arte e educação".

Começo pelo título da tese, composto por elementos que se relacionam ou foram produzidos a partir das posturas teórico-metodológicas adotadas. Problematização tem a energia foucaultiana relacionada à interrogação de certas políticas (entendidas como produtoras de lugares a serem ocupados pelos sujeitos) e das razões que as explicam, cujo fim permite observar as implicações entre uma estrutura política e uma prática moral (FOUCAULT, 2014b). A base das análises teóricas empreendidas é uma problematização que articula o pensamento foucaultiano ao de Jacques Rancière e Giorgio Agamben, entre outros autores. A segunda parte do título advém da parte artística da metodologia, identificada de forma geral como residência.

A tese visou problematizar as políticas da arte na licenciatura em artes visuais indagando sobre como certas operações produzem efeitos sobre os estudantes. Essa empresa deu-se desde a criação da metodologia a partir da atitude política de indagar as articulações com a arte na formação docente a partir de experiências que não necessariamente localizam-se no regime da arte, do que apropria-se o campo da educação para a formação de professores.

\section{Composição para uma metodologia}

De uma forma geral, a metodologia de pesquisa da tese reconhece-se em uma abordagem qualitativa marcada pela maneira com que se vê o mundo e pela orientação conceitual de atribuição de sentido ao que é visto na pesquisa. Tais

Criar Educação, Criciúma, v. 7, №1, jan/jul 2018.- PPGE - UNESC 
características contribuem ao pensamento sobre os diversos modos de como 0 saber pode vir a ser produzido (EISNER, 1998).

No conjunto dos procedimentos teórico-metodológicos, a arte foi uma maneira de multiplicar os modos de conhecer, sendo que diferentes modos de agir e de pensar foram empregados para, em relação, tocarem na mesma questão: que efeitos as formas de operar com a arte produzem ao sujeito da licenciatura em artes visuais? De que maneiras podem ser pensados esses efeitos em relação à atuação docente em artes visuais em escolas? Como o modo de ser de uma pesquisa sobre a formação docente em artes visuais pode contribuir para movimentar as formas de operar com a arte na licenciatura com o olhar voltado para a educação escolar em artes visuais?

A abordagem artística considerou a arte como um bem comum, assim como entendemos para a educação, o que toca no que concebo para o agir docente na escola, fim da formação realizada pela licenciatura. É um agir da ordem do político que tem a potência de perturbar os modos da experiência com a arte na educação escolar, geralmente inspirados pela ação do artista e do espectador ou por derivações produzidas pelo campo artístico. A arte como bem comum requer abrir mão da atenção obstinada sobre o sujeito - que expressa a si mesmo, fala de si mesmo, reflete sobre si mesmo - e do conhecimento como poder e propriedade de alguns. Aí que a atitude política do percurso metodológico, em lugar da expressão autoral e do objeto ou proposição inscrita no sistema de reconhecimento da arte, pretendeu desestabilizar o próprio objeto de estudo, permitindo deslocar as formas conhecidas de fazer pesquisa em educação, a noção de arte segundo o seu regime de reconhecimento e isso em relação à formação de professores em artes visuais.

O esforço de ampliação dos modos convencionais de pesquisar na educação, em última instância, pode contribuir para que as perguntas feitas pelo pesquisar não ocorram somente no espectro do conhecido, mas que proponham novas articulações entre o que existe ou novos modos de pensar. Assim, a tese desenvolveu-se a partir da reunião de quatro princípios que energizaram 0 pensamento sobre o seu objeto, a formação docente, na afirmação de: minha 
atuação como professora universitária; um entusiasmo investigativo; a articulação teórica entre filosofia, educação e arte; e a produção experimental em artes visuais.

A tese resultou de uma pesquisa baseada na arte, mas não pretende filiar-se às tipologias conhecidas. A a/r/tografia, por exemplo, caracteriza-se por considerar que arte, pesquisa e docência aconteçam simultaneamente, pois são artógrafos os professores que ao mesmo tempo são também artistas e pesquisadores, a própria designação demonstra isso. No meu caso, predomina a atuação docente em artes visuais e uma atitude artística não inscrita no campo das artes visuais. A produção artística que realizo é contingente, sendo essa sua natureza poética.

Estar "fora" - da legitimação da arte e da tradição da pesquisa acadêmica foi um posicionamento que pretendeu mais estar ao lado do que ser o contrário, uma negação ou uma sombra. Assemelha-se ao modo parasitário ou alterado (KWON, 2011) e à inserção de um próprio-impróprio (ROCKHILL, 2010) na ordem estabelecida. Quando a metodologia tensiona o objeto de pesquisa, contribui-se para diminuir o dogmatismo do conhecimento produzido.

Há pouco mais de uma década, a arte vem sendo introduzida nas pesquisas educacionais no Brasil. Compõem esse campo compreensões próximas, porém diferentes, como pode ser observado através do que é proposto em duas teses brasileiras recentes: metodologia artística de pesquisa em educação (EGAS, 2017) e pesquisa baseada em arte na educação (VASCONCELLOS, 2015). Em respeito ao contexto internacional, pode-se ter uma ideia da diversidade de abordagens pelo inventário realizado por Given (2008): autobiografia, bricolagem, colagem, etnodrama, etnopoética, fotonovela, narrativa visual, pesquisa baseada em crítica artística, fotografia, música, dança, poesia, literatura, apenas para citar algumas. A diversidade de metodologias de pesquisa em composição com a arte demonstra não apenas o entusiasmo pelo seu uso, mas um trânsito transdisciplinar que abrange a educação e as artes para além das metodologias tradicionais (CHARRÉU; OLIVEIRA, 2016).

Criar Educação, Criciúma, v. 7, no1, jan/jul 2018.- PPGE - UNESC 


\section{Residências Artísticas}

Em um primeiro momento, a inserção de uma experiência artística na pesquisa em educação sugere o estabelecimento de relações com o âmbito artístico: artista, obra, processo criativo, linguagem, performance, arte contemporânea, arte relacional, professora-artista, para citar algumas possíveis filiações que diferenciam o trabalho ${ }^{2}$. Há, porém, o alerta sobre os vários fetiches incidentes no meio educacional (LARROSA, 2014) e as estabilidades que com que o saber acadêmico da arte lida, cujas estruturas, herdadas da autonomia artística moderna que delineia um campo isolado da vida social, limitam sensivelmente o horizonte de conversa (BALDISSEROTTO, 2016). Para tratar da dimensão política da formação docente em relação às artes visuais, optei por tensionar noções da arte e da educação, ensaiando na pesquisa a ação política de dispor a arte ao uso livre, no terreno comum, projetando isso para a educação escolar em artes visuais.

Observar usos das residências nas artes visuais é importante para compreender algumas diferenças nos modos como foram ou são propostas. Residência é um modo de produção artística experimental, uma situação de criação que expande as noções representativas da arte, como o objeto artístico e a sua circulação e a ênfase na individualidade do artista. Hoje, é uma prática consolidada que tem como antecedentes as colônias de artistas da década de 1960 (MORAES, 2009) e, antes, aquelas do final século $X I X$ e primeiras décadas do século $X X$, quando artistas distanciavam-se em um espaço idílico, utópico, das contradições geradas pelo modernismo industrial. Atualmente, contudo, atribuem-se às residências um papel bem mais ativo porque representam alternativas para outras modalidades de inserção no contexto artístico (MORAES, 2009, p. 15).

A residência artística requer o deslocamento do artista de uma condição habitual de vida e de trabalho, estabelecendo a permanência temporária em um ambiente favorável e de convívio que objetivamente possibilite tempo e espaço para a criação (MORAES, 2009). Dalcol (2015, p. 3188) considera que o artista atua

\footnotetext{
${ }^{2}$ Itens citados com base em publicações em periódicos e trabalhos de pós-graduação.
}

Criar Educação, Criciúma, v. 7, ำ1, jan/jul 2018.- PPGE - UNESC 
como um viajante em um empreendimento artístico para o qual lança um olhar poético e crítico, impulsionando seu interesse "produzir, ao longo de um processo criativo, uma articulação de pensamento e investigação sobre o que não domina nem compreende" (DALCOL, 2015, p. 3180).

Pela atualidade e frequência com que vêm sendo realizadas, as residências artísticas podem ser acometidas de um apelo de contemporaneidade, podendo inclusive reanimar um halo romântico quando em conjunto às ideias de viagem e descobrimento. Além disso, há uma contradição de termos na ideia que circunda a residência artística: "Com sucessivos desafios em trânsito, ela substitui o antigo modelo do ateliê como fortaleza de trabalho pela experiência nômade. Mas, uma vez nômade, como o artista pode ser residente?" (MARQUEZ, 2013, p. 22).

Na pesquisa realizada, o deslocamento geográfico e o estado de suspensão e desconhecimento deram-se na mesma medida do encontro de uma circunstância conhecida para uma professora universitária. O deslocamento deu-se em direção ao habitual que, ao mesmo tempo, era tão outro. O percurso realizado foi nômade, no que não era totalmente desconhecido.

O papel da residência foi delineado com o aporte de outros usos dessa prática, não aqueles de artistas. A proposição do Centro de Criação Contemporânea Matadero Madrid, em 2016, convocou de forma aberta "criadores-educadores", dirigindo-se a artistas visuais que desejassem explorar experimentalmente o âmbito pedagógico sem cair nas práticas mais conhecidas do artista de ateliê ou do professor de artesanato. Mas também convocou educadores que considerassem fazer um trabalho artístico em seu fazer pedagógico, rompendo as barreiras habituais entre professores e alunos.

Já as residências promovidas pela Curatoría Forense, organização chilena formada por um grupo multidisciplinar dedicado à arte latino-americana recente, orientam-se para a construção de uma rede que parte da "criação e consolidação de relações afetivas e efetivas e da promoção da produção e circulação de conhecimento e interações com o objetivo de triangular arte contemporânea e debate com a comunidade" (CURATORIA FORENSE - LATINOAMÉRICA, [s.d.]).

Criar Educação, Criciúma, v. 7, ำ1, jan/jul 2018.- PPGE - UNESC 
Vale citar ainda o Projeto Pedagógico da 7ª Bienal do Mercosul, Artistas em Disponibilidade. Segundo essa proposta, o "capital pedagógico" ou a possibilidade educativa do artista residente em escolas estimularia tanto o diálogo quanto o seu confronto com a educação formal (DE CARO, 2009). Uma ação pouco hierarquizada dessa natureza, mesmo que promovida por um vetor forte do sistema da arte como uma bienal, encoraja os artistas a tomarem atitudes direcionadas a um pensamento social, ao mesmo tempo em que concebe arte e educação (mas também artistas, professores, alunos e pessoas comuns) como partícipes do mesmo mundo.

Meu principal interesse nas artes compreende maneiras de atuar artisticamente na vida de professora de artes visuais, modos que existem fugazmente, pois são criados conforme o ir e vir entre aulas, deslocamento entre diferentes cidades, orientação de trabalhos e estágios e estudos. Podem ser entendidos como descompromissados ou, de outro modo, como atos e construções que nascem da fugacidade e da contingência. Isso caracteriza um trabalho que se dá apenas nas frestas da profissão, mas que, ao mesmo tempo, é produto da própria docência.

Parte dessa energia artística vem do Armazém de Histórias Ambulantes, uma carroça itinerante que troca histórias no Parque da Redenção, em Porto Alegre (RS). Coordenada por Ana Flávia Baldisserotto, artista e professora de artes visuais, conta com pessoas agregadas ao projeto por afinidade. É uma espécie de "negócio dinâmico" que vende histórias, pagas com outas, doadas (como cartas ou escritos de gaveta) ou contadas na hora. Como pagamento, aceita qualquer tipo de história, sem avaliações prévias: "histórias vividas, inventadas, alegres ou tristes, engraçadas ou trágicas, lidas, sonhadas ou escutadas, histórias sem começo, histórias sem fim, histórias boas ou ruins" (ARMAZÉM DE HISTÓRIAS AMBULANTES, [s.d.]).

O "estabelecimento" é uma carroça vermelha com um guarda-sol amarelo como as que vendem pipoca, comuns naquele parque. Busca formar um campo de contato, de movimento e de liberdade a partir da realização de desejos sem um porquê (BALDISSEROTTO, 2016, Doc. Eletrônico). O percurso entre o desejo da artista em ter uma carroça à existência do Armazém como uma coletividade, promove condições para exercícios de liberdade que, enquanto atitude, afirmam a

Criar Educação, Criciúma, v. 7, no1, jan/jul 2018.- PPGE - UNESC 
vida que existe e resiste, no parque. Daí entender que empurrar a Carroça é atitude e movimento de instalação no comum e ser ambulante é o estado de disponibilidade para uma experiência imprevisível, na rua.

\section{Papel almaço, esgotar um lugar, ambientes de conversa e cadernos de residência}

A pesquisa lidou poética e politicamente na geração de sentidos sobre o que é dado às formas de sentir (RANCIĖRE, 2009) contextualmente em cada residência. Estar nos lugares onde ocorriam cursos de formação docente e com as pessoas que os levam a existir sem determinar antes os eventos mais representativos, porém acolhendo o que a residência propiciasse em relação ao espaço, às aulas, ao encontro com estudantes e professores, foi a maneira de gerar sentido a partir do que lá pudesse ser produzido. As conversas com professores e alunos e as situações de presença no espaço, mesmo que tenham ocorrido em diferentes níveis de preparação e de improviso, todas deram-se em um necessário estado de disponibilidade.

Residência foi a forma geral da experiência/sentido suplementar ao pensamento construído a partir do par teoria/prática (LARROSA, 2014), mas também o modo de pesquisar com arte na educação de uma forma viva, habitante do terreno de investigação e necessariamente com os que participantes. Realizei duas residências em universidades públicas em extremos do Brasil, Belém no Pará e Pelotas no Rio Grande do Sul, cuja distância geográfica embasou a geração de conhecimento a partir de lugares periféricos às pesquisas mais divulgadas, do centro do país. Estive na Universidade Federal do Pará (UFPA) e na Universidade Federal de Pelotas (UFPEL), entre norte e sul, calor e frio, mas também entre rios, licenciaturas em artes visuais e em contato com a jovialidade das ideias dos licenciandos que contagiou a tese, participando de sua sustentação.

A residência oportunizou uma circunstância para a presença nos lugares onde ocorriam os cursos, o que considero ser um primeiro sentido para tal experiência. Cada período compreendeu uma quinzena e o seguinte protocolo: na primeira semana, estar nas manhãs e nas tardes onde os cursos ocorriam, conversar com

Criar Educação, Criciúma, v. 7, №1, jan/jul 2018.- PPGE - UNESC 


\section{CRIAR EDUCAÇÃO}

Revista do Programa de Pós-Graduação em Educação - UNESC

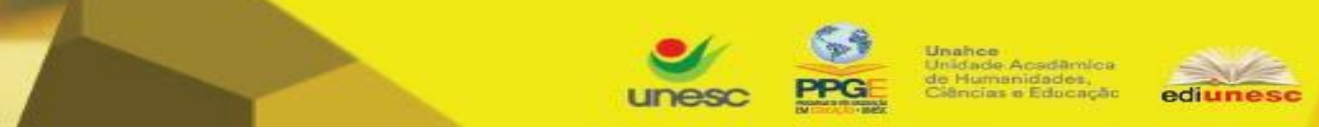

professores, assistir aulas e ler trabalhos de conclusão e planos de curso. Quando não havia compromisso marcado, explorei cada local e arredores, esgotando-os por meio de escrita, fotografias, aquarelas e desenhos, aludindo à tentativa de Georges Perec (2016) em esgotar um lugar. Além disso, levei uma grande porção de folhas de papel almaço, eram como um elemento-síntese do estado de todo estudante. As folhas, que foram inseridas na pesquisa inicialmente em condição potencial, ganharam sentido e acompanharam toda a pesquisa e a análise de dados, formando uma base prática para pensar o tema da tese.

O papel almaço é tanto uma folha ampla e dobrada, composta por quatro páginas, quanto o papel símbolo da escrita burocrática, das provas, das atas e da contabilidade. Para os padrões de hoje, o seu tamanho é estranho porque é maior que as folhas que manuseamos e a altura é a dimensão que mais se impõe. Ele é austero, tem frente e verso pautados com 35 linhas em azul bem claro e tem margens na cor rosa, algo leve para linhas de tradição tão marcada e cuja configuração resiste no tempo e subsiste inclusive no ambiente acadêmico ${ }^{3}$.

\footnotetext{
${ }^{3}$ Há instituições de ensino superior que mantém o papel almaço timbrado para a realização de provas ou trabalhos feitos pelos alunos.
}

Criar Educação, Criciúma, v. 7, ำ1, jan/jul 2018.- PPGE - UNESC 


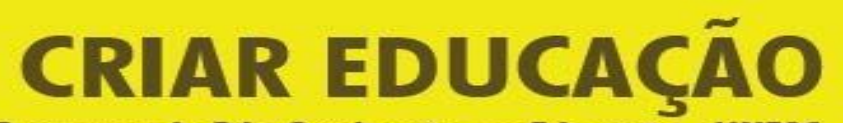

Revista do Programa de Pós-Graduação em Educação - UNESC

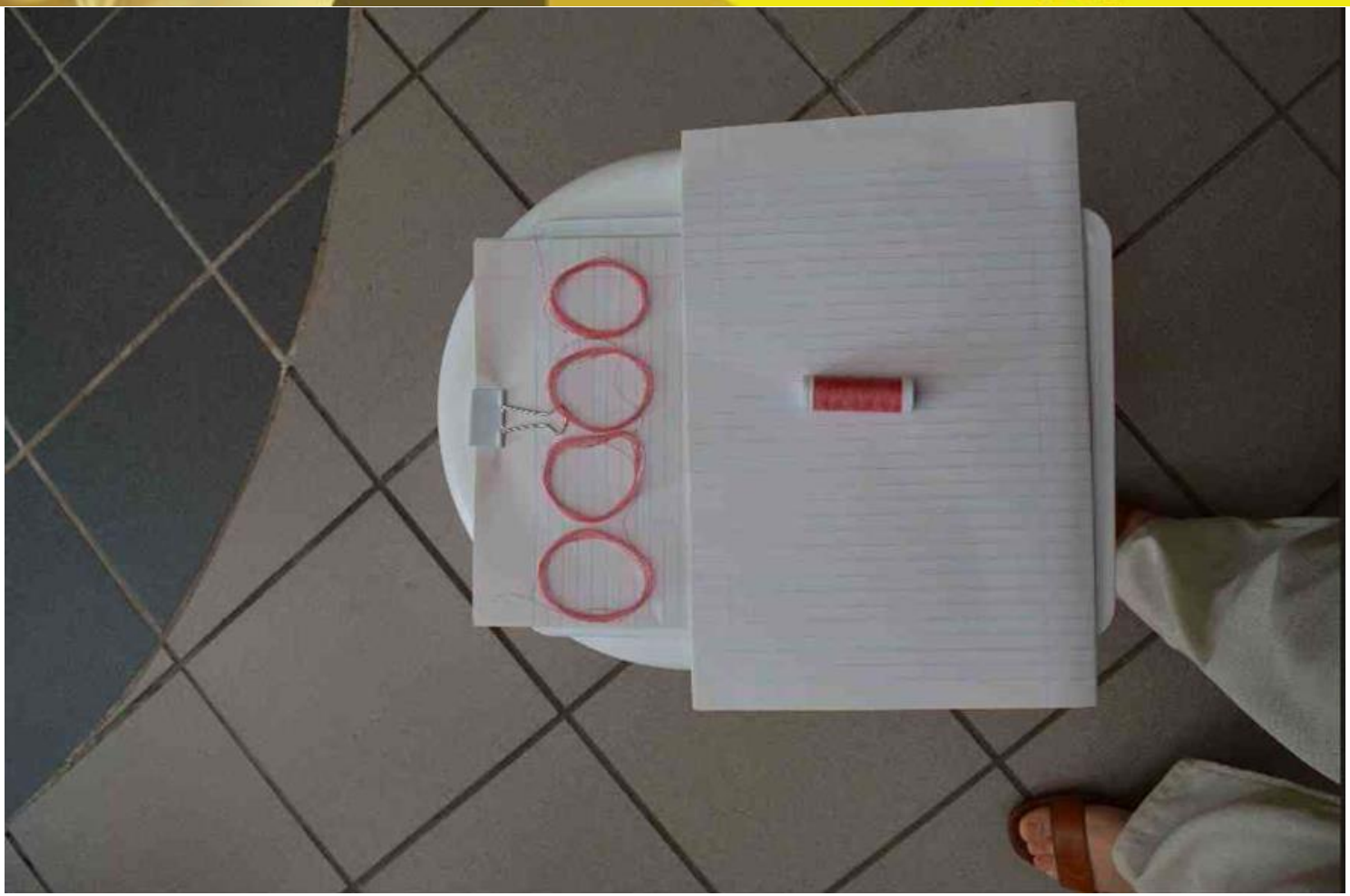

Ambiente de conversa, dia chuvoso, saguão do Centro de Artes (CA), UFPEL. Trabalho com as folhas almaço. Abril de 2016. Acervo pessoal.

Tomei aquela grade ritmada como ponto de partida de uma série de ações para encontrar ali outras extensões, dimensões e sentidos. A fartura do material permitiu que uma ação fosse realizada em cada folha, devagar, constituindo vários exemplares que pude produzir, manusear e observar sem pressa, durante todo 0 ano dedicado à pesquisa (2016): cortes, dobras, montagens, desmontes.

Criar Educação, Criciúma, v. 7, №1, jan/jul 2018.- PPGE - UNESC 


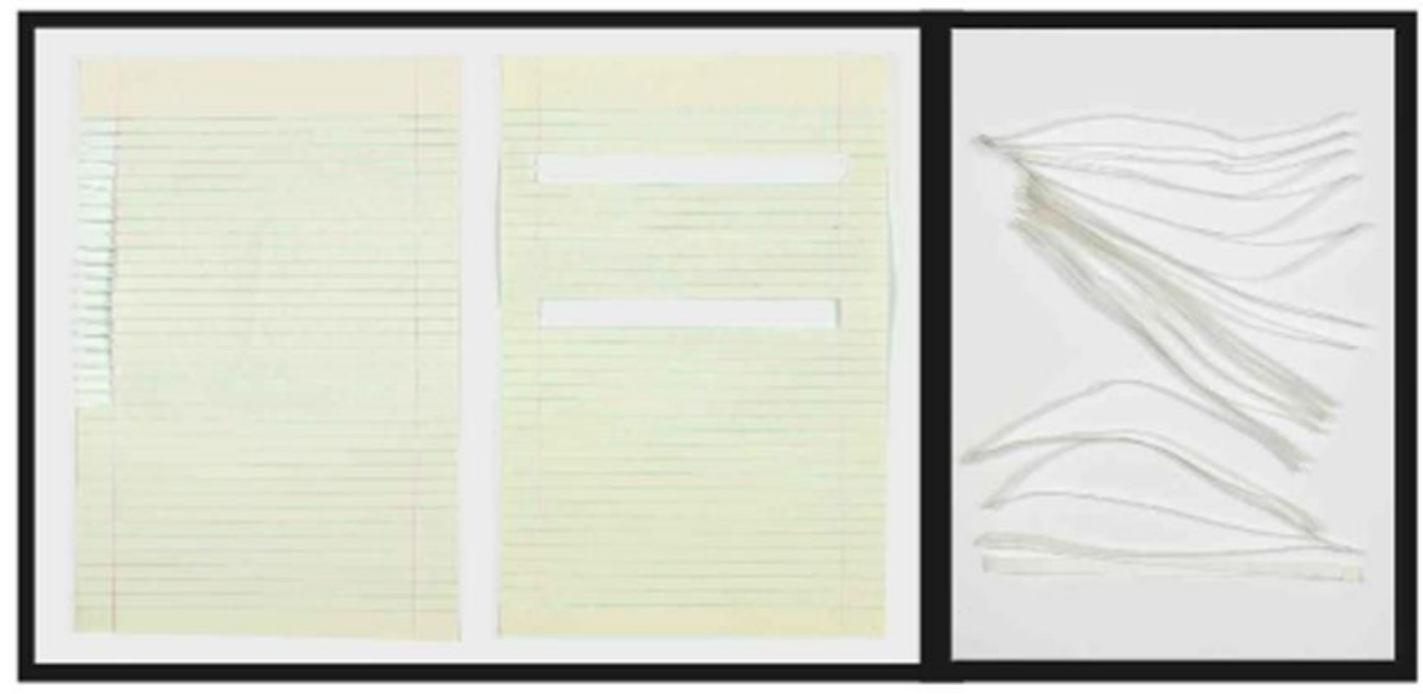

Papel almaço. 2016. Acervo pessoal.

Foi assim que o pensamento da tese foi sendo construído entre imagem e texto, e, mesmo o texto requerendo mais tempo, o trabalho poético experimental existiu também como uma resistência à conformação da experiência investigativa pela escrita acadêmica. Daí a importância em ter feito a pesquisa também produzindo imagens, trazendo a contribuição das artes visuais à geração de pensamento que não haveria possibilidade de vir a ser apenas pela escrita científica.

O estado de permanência e suspensão foi outro sentido adquirido pela residência. Atuar com um protocolo aberto de pesquisa permitiu que a segunda semana do período fosse criada contextualmente em cada universidade. Se a primeira semana abarcou atividades mais estáveis, a segunda foi sendo criada pela permanência naqueles lugares. Para estar com os alunos das licenciaturas, precisava identificar a condição necessária a um encontro que proporcionasse um estado de conversação o mais horizontal possível ${ }^{4}$. Daí veio o terceiro sentido das residências, uma condição para a produção artística experimental contextualizada, o

\footnotetext{
${ }^{4}$ Mediante o intenso trabalho que realizavam e os poucos horários disponíveis, na maioria das vezes conversei com os professores nas salas dos prédios. Contudo, também realizamos caminhadas pelo campus e estivemos nos cafés, próximos, conforme sua sugestão.
}

Criar Educação, Criciúma, v. 7, №1, jan/jul 2018.- PPGE - UNESC 


\section{que conecta-se ao que analisa Paul Ardenne (2006) sobre o vínculo estreito de} algumas proposições da arte com o contexto onde ocorrem.

Compus dois kits de aparatos para conversar. Em um hipermercado de Pelotas, comprei dois banquinhos dobráveis, uma tábua de corte, clipes de papel, uma caixa plástica e uma corda de varal para colocar em circulação narrativas por mim colecionadas, disparando a conversa com os alunos das licenciaturas. As narrativas traziam a fala de estagiários e professores de Arte sobre situações que relacionavam a docência e a prática artística existente ou não. Eu e o kit pelotense fomos ambulantes nos arredores do Centro de Artes, escapando da chuva e do sol intenso, mas sempre em aproximação e disponibilidade aos alunos, principalmente, mas também aos professores dos cursos.

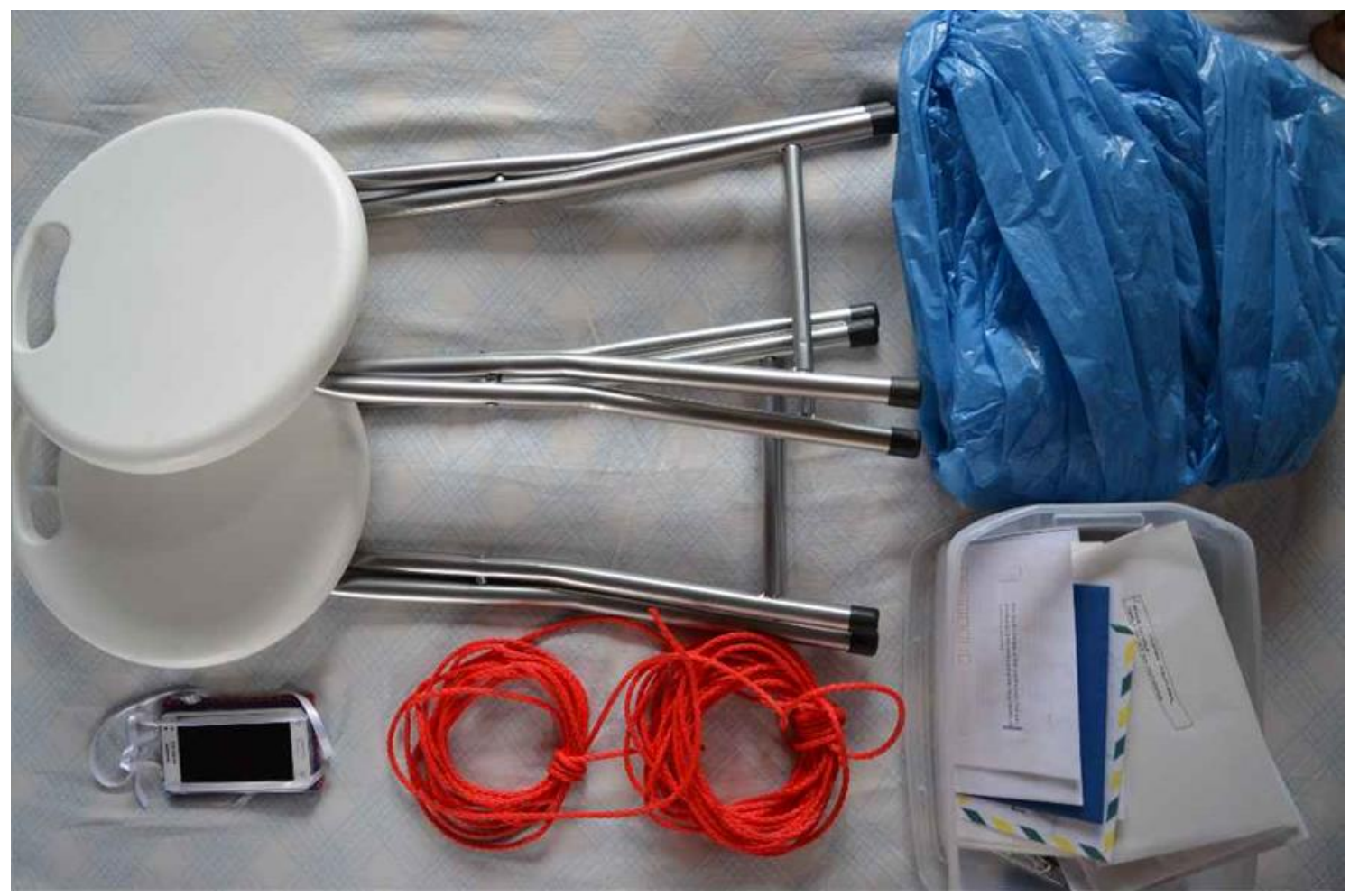

Kit de aparatos para conversar, Pelotas. Abril de 2016. Acervo pessoal.

Criar Educação, Criciúma, v. 7, ำ1, jan/jul 2018.- PPGE - UNESC 


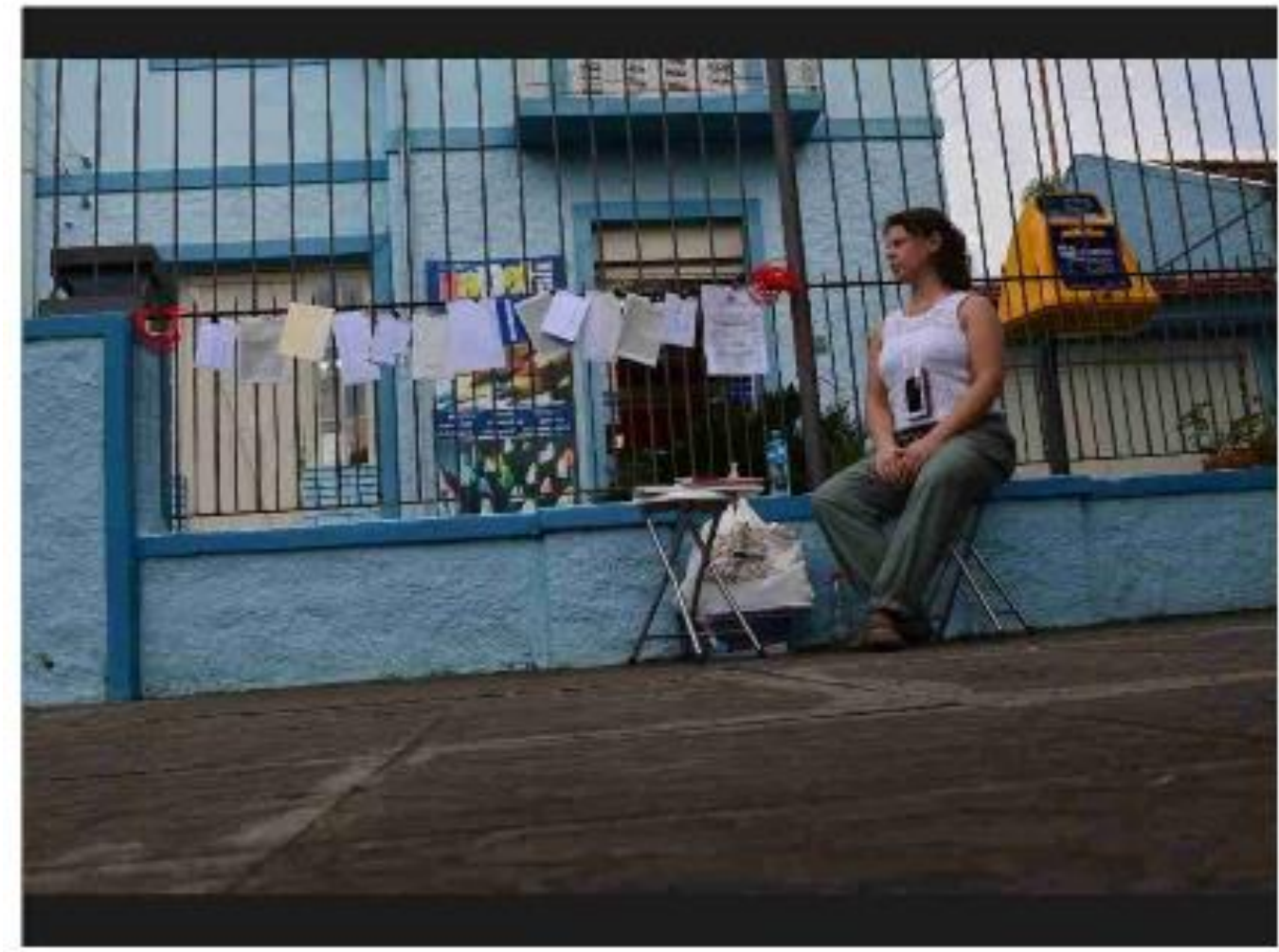

Ambiente de conversa, Xerox do Glênio, UFPEL. Abril de 2016. Acervo pessoal.

O kit belenense de aparatos para conversar foi adquirido em uma região de intenso comércio popular nas cercanias do campus da UFPA. Instalar-me com almofadas coloridas sobre um pano de estampa "amazônica", assim como estive, antes, em um banquinho na calçada, encontra-se com um "modo de habitar o mundo de um ser que existe, de um ser que não tem outro ser, outra essência, além da sua própria existência corporal, finita, encarnada, no tempo e no espaço, com outros" (LARROSA, 2014, p. 43). Com os alunos, não estive bem dentro da academia, mas perto e por fora. Entendi ser necessário ir em direção ao mundo frequentado por eles e com elementos comuns e, embora em uma montagem estrangeira ao ambiente daquele cotidiano, os ambientes de conversa faziam um convite a qualquer um e distinguiam menos as posições ocupadas pelos indivíduos na universidade.

Criar Educação, Criciúma, v. 7, ำ1, jan/jul 2018.- PPGE - UNESC 


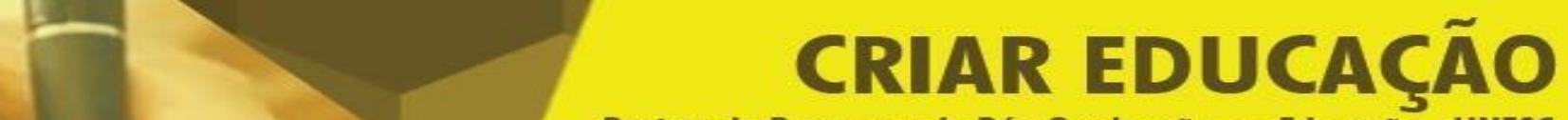

Revista do Programa de Pós-Graduação em Educação - UNESC

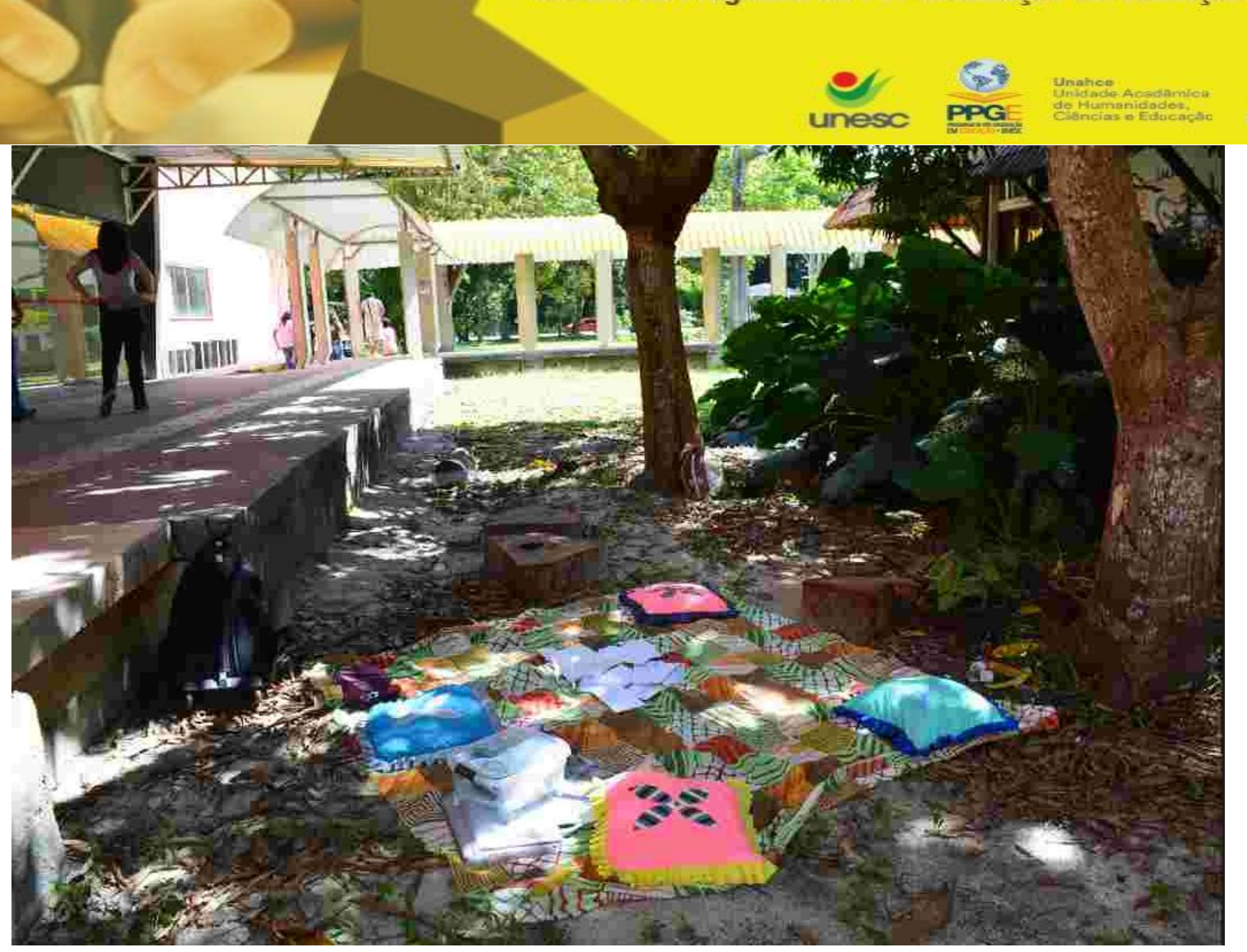

Ambientes de conversa entre os prédios da Faculdade de Artes Visuais, UFPA. Junho de 2016. Acervo pessoal.

À espera das conversas, tinha o telefone pendurado no pescoço para fazer a gravação do áudio, pois imaginei ser útil estar com as mãos livres para receber as pessoas. Foi rápido, contudo, descobrir que era impossível realizar atividades produtivas durante a espera, como estudar ou escrever, por exemplo. Isso dificultava a aproximação do outro, pois era necessário estar completamente disponível, como se todo o aparato - e eu, nele - dissesse sim para qualquer coisa que ocorresse, incluindo acontecimento algum. A escrita dos cadernos de residência teve que ser transferida para os momentos de solidão nos prédios dos cursos de arte ou fora deles, procurando sorver ao máximo o que tinha vivido:

Devia ter escrito antes, ontem. Tem sempre uma urgência e essa palavra apareceu hoje: urgência em recolher o que foi oferecido, recolher tudo ou ao menos tudo o que puder abraçar. Não é possível colher enquanto se recebe, se colhesse ou recolhesse, pararia de receber. Ontem a oferta foi grande, algo como a expressão que me ocorreu antes de chegar na cidade: travessia pelo sim. Ir para a aula? Sim. Comprar os materiais? Sim. Aguardar? Sim. Não saber como agir? Sim. Desenho com modelo vivo? Sim, ela faz a pose clássica. Olhar para a aula em si, pensar no desenho,

Criar Educação, Criciúma, v. 7, №1, jan/jul 2018.- PPGE - UNESC 


\section{CRIAR EDUCAÇÃO}

Revista do Programa de Pós-Graduação em Educação - UNESC

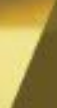

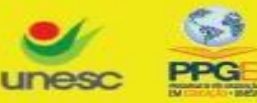

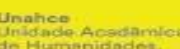

escorregar o olhar para o desenho dos outros, pensar nessa aula em uma licenciatura, ativar o que eu mesma fazia ali, será que está ficando bom meu desenho? [...] Só o desenho daquela moça, contava. Aqui e ali soava: mais volume, está ótimo, está longilínea, observa bem, tem algo mais ali, está pronto. [...] Logo já estava em um grupo de pesquisa que trabalha explorando livros e bibliotecas como tema: uma biblioteca que encolhe, outra que se muda, a palavra que se apaga. $O$ que fazer com o que é percebido no mundo? Que acontece no seu mundo? Faziam alguma coisa juntos, juntando e colhendo ideias e forças de todos os tipos e intensidades, porque coisas são feitas por querer, por maravilhamento, só por isso. Quase não fui a esse encontro e quase perdi algo muito especial, muito mesmo. Tomada de cansaço e alguma impaciência, ensaiei ir embora, mas a professora que coordenava o grupo queria que eu estivesse no encontro da pesquisa. Ela me fez ficar: em vez de pressa e agitação - o que nunca vejo nos alunos -, tempo e desejo. [...] Foi bonita a comunhão de ideias sobre experiências com educação e arte, que, na verdade, são experiências com outros e com o que é possível que cada um invente. Coisas ocorrem quando se é ou está disponível para fazer coisas juntos. Estar juntos e com o tempo nas mãos: chaves para invenção. [...] Se há uma urgência na licenciatura, é a de tomar o curso como uma forma por ser criada como o que pensei, agora: juntos e com tempo, disponíveis ao maravilhamento pela arte e pela educação e cada uma com as suas tragédias. A maravilha e o trágico precisam estar na roda, serem ditos, escritos, terem os seus perigos avisados [...] (Caderno de Residência, UFPEL, abril de 2016, em casa).

Curiosamente, trabalhar sobre as folhas pautadas durante a espera tornou-se uma atividade que gerou aproximação. Entre cortes, dobras e linhas, criei uma espécie de lembrança dada aos participantes da pesquisa: um corte específico em um maço de folhas, abrangendo apenas o espaço de uma linha. Quando os interessados chegavam, eu explicava que tudo aquilo era uma pesquisa de doutorado - os bloquinhos de uma linha, os envelopes no varal, os bancos, eu mesma, ali, o que na maior parte das vezes produzia um sorriso. A partir daí, procedíamos assim: um envelope contendo uma narrativa era escolhido e lido em voz alta e então, conversávamos. Em algum momento o termo de consentimento era lido, assinado e o bloquinho, dado, com meu e-mail. 
Não tenho essa dúvida, não tenho. Eu desconstruí essa dúvida. Eu acho que o bacharelado lida muito com a solidão. É muito... o seu processo criativo, as coisas que você observa, é a sua "solitude" na verdade, o bacharelado. E a licenciatura... é um gramado, uma praça. A licenciatura é muito uma praça. Aí eu acho que é desse jeito que acontece. O que acontece quando estou sozinha? Eu vou à praça, faço essa ponte entre essas coisas porque a praça é um lugar de tanta troca cultural, é um lugar educativo. E hoje em dia elas são tão projetadas que é triste, chato. (Aluna, UFPEL, abril de 2016, Café da Cátia).

Eu acho que, pensando dessa forma, eu comecei a gostar de arte de outro modo. É igual como pensar na rua como espaço expositivo, onde a arte se dá e acontece, sabe? Só que lá você tem esse espaço. O espaço ele acontece como você pensa nele. Eu acho totalmente necessário a gente questionar isso e levar para a sala de aula os espaços como eles se dão e a questão conflituosa de como a gente pode interagir com esse espaço e resolver essas questões. [...] a licenciatura, ela é muito dividida. Total, porque, por exemplo, aquela questão que te falei das pessoas que não têm contato com arte desde sempre, elas estão em um processo muito mais lento de aprendizado e de aceitação de espaços de arte, de espaços contemporâneos, de espaços públicos e como a arte se dá nesses espaços é muito diferente de quem já teve um outro contato e já pensa nisso. Eu vejo muito a galera achando que a arte só se dá em espaço expositivo, sabe? E esse conflito aqui: por que essa parede é arte ou o que não faz dela arte e o que está na galeria, faz? Então acho que tem que questionar os espaços e como eles abrigam a nossa arte e a arte do mundo. (Aluno, UFPEL, abril de 2016, saguão do Centro de Artes).

Nos primeiros dias, além de produzir horas de entrevistas, estive a andar pelos prédios e arredores ou a ficar em algum lugar dentro ou fora, ao redor, disposta aos espaços e aos ritmos de cada lugar. Não que ficasse examinando, ao contrário: era uma tentativa de entrar e estar em um tipo de abertura, acessando algo que escapava da organização funcional ordinária.

Tinha ares da pergunta de Perec comigo:

O que acontece realmente, o que vivemos, o resto, todo o resto, onde ele está? $\mathrm{O}$ que acontece a cada dia e que sempre retorna, o banal, 0 cotidiano, o evidente, o comum, o ordinário, o infraordinário, o ruído de fundo, o habitual, como dar conta disso, como interrogá-lo, como descrevêlo?

Interrogar o habitual. Mas justamente, estamos acostumados a ele. Nós não o interrogamos, ele não nos interroga, ele parece não causar problemas, nós o vivemos sem pensar nisso, como se ele não veiculasse nem perguntas nem respostas, como se não fosse portador de qualquer 
informação. Não é nem mais condicionamento, mas anestesia. Dormimos nossa vida em um sono sem sonhos. Mas onde está nossa vida? Onde está nosso corpo? Onde está nosso espaço? (PEREC, 2010, p. 179).

Procurando a vida e o espaço que se ocupa na universidade, compus uma coleção de fotografias, gravações curtas de áudio e dois cadernos de residência onde há relatos, desenhos, listas, rumores dos estudos, enfim, uma variedade de tipos de pensamento sobre as coisas mais comuns e talvez ruidosas que cercam a formação docente em artes visuais. A residência foi construindo-se, algumas vezes pela produção de escrita, desenho e aquarelas nas cercanias, outras pela escrita produzida in loco, nos prédios, mera presença:

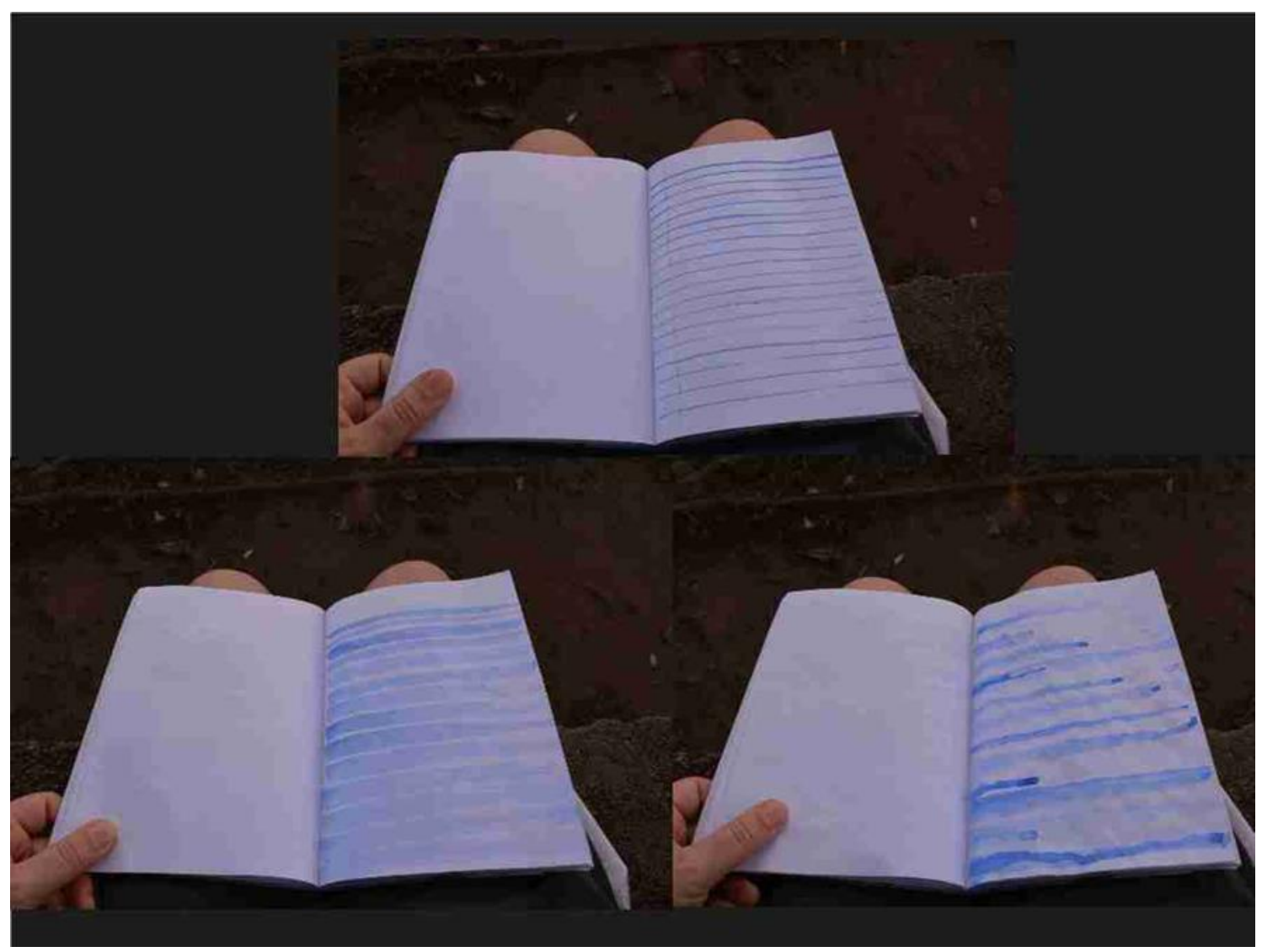

Caderno de residência, beira do rio, arredores da Faculdade de Artes Visuais da UFPA. Junho de 2016. Acervo pessoal.

[...] Tem um objeto pendurado próximo a mim, três meninas saem do corredor à esquerda e balançam ele. Em pouco tempo, um minuto talvez,

Criar Educação, Criciúma, v. 7, №1, jan/jul 2018.- PPGE - UNESC 
ele quase para. De uma sala sai alguém e passa a chave. A moça inquieta levanta e vai novamente à porta. Um rapaz vem de lá do corredor à frente, silencioso e devagar. Ela agora segura a jaqueta na mão. Outro rapaz sai da minha esquerda. Duas moças vêm do banheiro ou da escada, conversando.

São duas as salas ocupadas, apenas uma está, acho, com a porta aberta. Começam a mexer móveis, cadeiras certamente, mesas talvez. A agitada sai da sala com a jaqueta vestida. Sai rápido. À frente dela, um rapaz de barba sai mais rápido, desce a escada à sua frente, olhando o telefone. Tinha uma bolsa cruzada nas costas. Mais uma moça e outra cruzam de um para o outro corredor. Umas pernas, lá no térreo, saem pela porta principal.

[...] Consigo identificar um grupo conversando, talvez duas moças e um rapaz, talvez um professor e alunas, talvez uma professora, uma aluna e um aluno. Talvez, todos alunos. Cai um silêncio. Alguém tosse. O objeto pendurado está quase imóvel. Quase certo que é um professor. São $11 \mathrm{~h}$ 15min. (Caderno de Residência, UFPEL, abril de 2016, 10h, segundo andar do Centro de Artes).

O prédio era um continente: alunos entrando e saindo; eu, parada, escrevendo; aquele objeto suspenso, talvez fruto de um experimento; professores e alunos, em aula. Salas abertas, com gente dentro; salas vazias, fechadas à chave; corredores e escadas, sob meu olhar e presença. Ainda tenho a viva sensação das coexistências dos tempos da vida, da rotina universitária, do protocolo da pesquisa, como se fossem camadas paralelas, às vezes sobrepostas, do que podemos nitidamente ver os contornos. Estava com os sentidos atentos e trabalhando para que sentidos novos daquele continente pudessem surgir. Com exceção daquele objeto pendurado do teto até quase tocar o chão, bola grande que parecia ser de papel ao alcance do corpo de qualquer um, tudo ali contornava-se pelos nomes, tempos, funções e espaços que ocupavam. Somente agora, novamente escrevendo para acessar um estado de pensamento, entendo pela bola suspensa que o estado experimental, de suspensão e disponibilidade a qualquer um, aproximava-se do que tinha em mente para a pesquisa e que, mais tarde, compôs as proposições da tese sobre a arte na formação de professores. Na bola suspensa, tanto por pensar.

Uma última referência é importante: o artístico produzido na tese, pensado para a formação docente e a arte na escola, harmoniza-se com a ideia do ser que vem, o qualquer (AGAMBEN, 2013). O produto artístico que tem a sua singularidade no seu ser tal qual é, desvincula a singularidade "do falso dilema que obriga o

Criar Educação, Criciúma, v. 7, ำ1, jan/jul 2018.- PPGE - UNESC 
conhecimento a escolher entre a inefabilidade do indivíduo e a inteligibilidade do universal" (AGAMBEN, 2013 p. 10) do ser qual. Nem experiência indizível, nem categoria reconhecível, a arte foi o modo de produzir o que um ser-tal em seu próprio pertencer. É uma originalidade que que não tem relação com um puro princípio criativo, autônomo ou de origem. É bom deixar de lado possíveis temores sobre a escuridão que isso possa representar, pois se consideramos que os tempos que vivemos são assustadores, concordando com Esche (2015), precisamos de ideias tão ou mais potentes para lidar com eles.

\section{As Histórias nas Conversas}

Era intenção que as conversas com alunos fossem pouco hierarquizadas para que pudéssemos abordar juntos alguns conflitos produzidos na licenciatura em artes visuais. Essa função foi desempenhada pelas narrativas que levei comigo e que deram circulação a histórias sobre o que cerca a licenciatura em artes visuais, agora narradas por professores que ganharam voz pelos próximos professores, naquele momento, em formação. Em Larrosa (2014) encontrei uma forma de sustentar o encontro produzido: escutar, em vez de compreender, e talvez oferecer em troca a capacidade para escutar o que talvez não compreendesse. Estaríamos juntos falando em uma língua que não falava por si mesma, mas dirigia-se a nós, pois: "Sabemos que falar e escrever, escutar e ler, são só possíveis pela própria pessoa, com os outros, mas pela própria pessoa, em primeira pessoa, em nome próprio" (LARROSA, 2014, p. 66).

Por dois anos, reuni narrativas de professoras e professores, atuantes em escola e ateliês, artistas e estudantes de pós-graduação. Escolhi as que expressavam de forma direta os conflitos existentes entre as artes visuais e a educação ou a docência e que motivariam o meu encontro com os alunos e também, mas de forma indireta, as conversas com os professores. Das 13 narrativas, cito alguns trechos:

Não me considero artista, sou professora de artes visuais. Penso que para poder ser artista, seria preciso complementar os meus estudos e cursar o bacharelado em artes visuais. Além disso, no curso de licenciatura

Criar Educação, Criciúma, v. 7, nำ1, jan/jul 2018.- PPGE - UNESC 
em artes visuais que fiz não tive tantas disciplinas de ateliê, de modo que não me sinto preparada para desenvolver minha poética em alguma linguagem estudada. (Narrativa I, 2015, acervo pessoal).

A turma de pós-graduação em artes visuais estudava um texto que afirmava que as definições de campo e de mundo da arte talvez não sejam mais suficientes para pensar 0 atual estado da arte contemporânea. A turma discutia a questão. Alunos e professora opinavam e retornavam ao texto, uma aula bastante dinâmica em torno da questão. A certa altura, a professora diz que talvez o que o autor estivesse dizendo é que a arte contemporânea, por hoje existir interdisciplinarmente, é uma arte muito aberta. Não tem mais como ser vista como um sítio ou um mundo à parte. Um aluno fez a seguinte observação: lá estavam 11 alunos, 6 de doutorado e 5 de mestrado, no instituto de artes, no último andar do prédio, em uma sala fechada. 11 alunos e uma professora pós-doutora discutindo como a arte se expandiu e hoje é aberta. (Narrativa II, 2015, acervo pessoal).

Demorei para me reconhecer como tal, mas, após quatro anos de exposições anuais, percebi que posso sim me considerar uma artista. Acredito que parte desse receio em me reconhecer como artista tenha vindo justamente do fato de eu ter cursado licenciatura e não bacharelado em artes visuais. [...] A faculdade de licenciatura nos ajuda a abrir os olhos para o mundo da arte, dando uma breve pincelada em questões da prática artística. Daí em diante acredito que deve partir de cada um continuar a postura investigativa não só como professor, mas como artista sim, porque não? (Narrativa III, 2015, acervo pessoal).

Os grifos indicam os critérios iniciais que produziram as questões da tese porque levantam as permissões e limites não explicitamente concedidos ou negados, mas facilmente identificáveis, entre a docência e a experiência artística da docência desde a formação na licenciatura. Além disso, chama atenção a suposta abertura da arte, proferida de dentro do próprio campo de origem, mas não pelos campos aos quais ter-se-ia aberto.

As histórias dos professores podiam

desestimar qualquer ideia ou vestígio de normalidade, de hábito, do encolhimento de ombros que significa que as coisas são assim mesmo. Ali é onde morre parte do mundo e, também, parte de nós mesmos. (SKLIAR, 2014 , p. 149, grifo do autor).

Chamei de dispositivo de conversa o seguinte: um varal onde foram pendurados os envelopes com as narrativas, além do termo da pesquisa, com dois banquinhos ficavam próximos. Ou o pano esticado à sombra, com as almofadas e os 
envelopes em cima. Em cada envelope, fiz um corte que permitia ler uma frase do texto impresso. Alguns leram e conversaram comigo sobre mais de uma narrativa e a maioria leu em voz alta, muitas vezes sorrindo ao identificar uma situação conhecida. Outros leram em silêncio ou quiseram trocar um envelope por outro. Quem escolheu um envelope não desistiu da conversa.

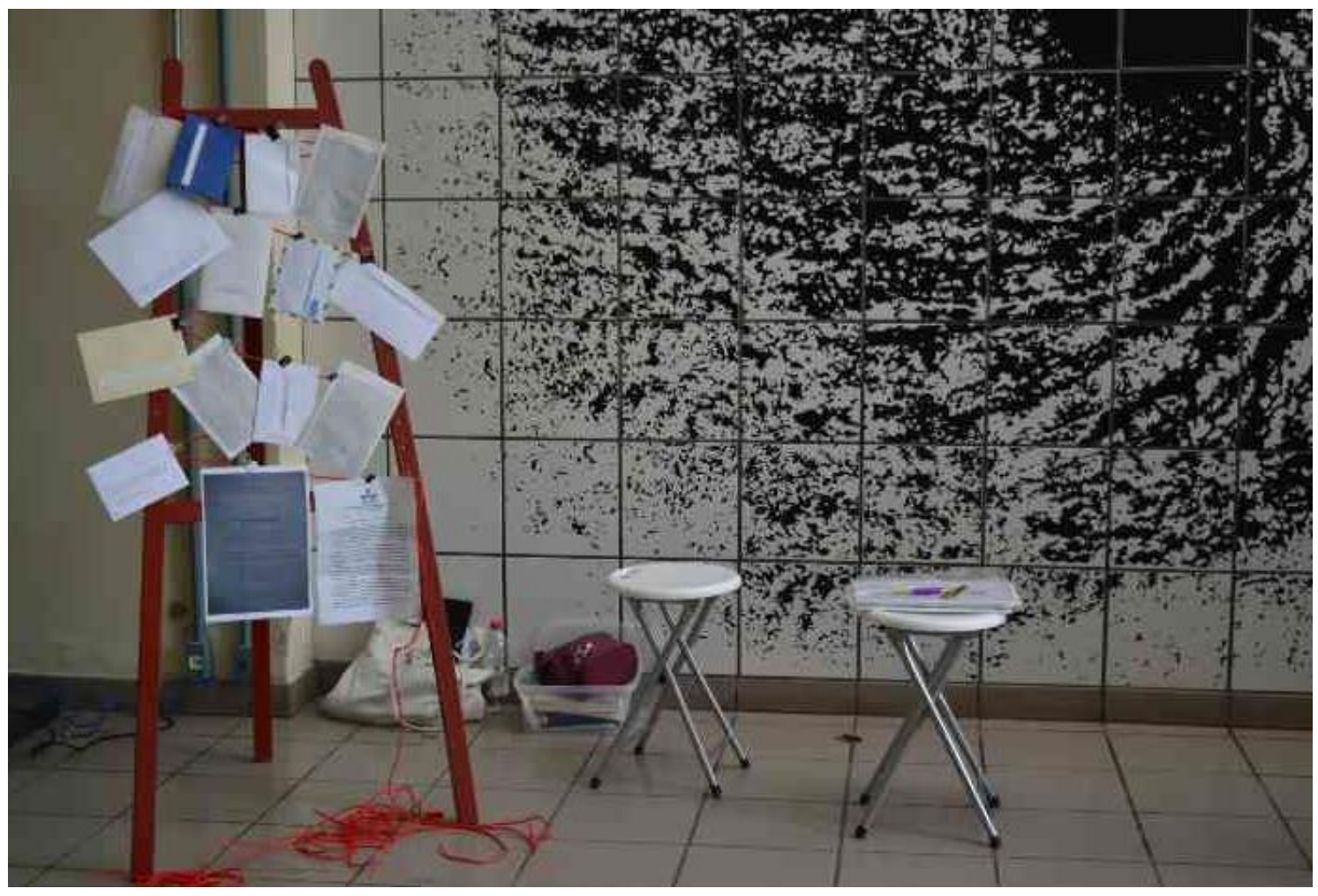

Ambiente de conversa, saguão do Centro de Artes, UFPEL (o dispositivo em um cavalete, equipamento do CA). Abril de 2016. Acervo pessoal.

Fazer circular as narrativas permitiu dar um lugar às histórias que, apesar de flutuarem nas conversas aqui e ali, levemente, permanecem sendo produzidas. Histórias sem lugar vivem em salas de aula ou em reuniões acadêmicas, quando uma fricção áspera entre arte e educação ocorre. Além disso, as histórias em conjunto tornaram identificáveis a posse ou a privação da posse da arte pelos professores, o que vibrava em oposição ao que o campo artístico dizia existir, uma abertura incomparável. Daí seguir coletando outras vozes, rastreando o discurso raro e rarefeito sobre a formação docente e os efeitos produzidos a partir das operações com as artes visuais, em um tal estado que estabelecia "um contínuo entre os sujeitos que somos, a linguagem que nos tornamos, a ética em ato que é 
essa escuta" (MESCHONNIC, 2015, p. 4). Uma atitude como essa, de escuta, pode também ser uma política da arte e uma política do pensamento na formação de professores que atuarão na educação básica.

\section{Não é a última página: revisão da formação docente com vistas à educação em artes visuais na escola}

Ao descrever a composição da metodologia criada para a recente tese, pretendi compartilhar as escolhas teórico-metodológicas que a embasaram. Isso pode incentivar que as pesquisas em educação e arte sejam instrumentos motivadores de renovação acadêmica, mas também que promovam certa abertura do saber produzido, diminuindo a distância entre pesquisadores, professores, artistas e professores de arte em escolas. Se multiplicarmos os modos de conhecer e, com isso, abrir os contornos que tradicionalmente definem arte e educação e as experiências com arte e com educação, tornaremos mais próximo e possível que arte e educação constituam-se como bens comuns. O contrário disso é a existência de comunidades puras (AGAMBEN, 2013), cujo saber tem proprietários bem marcados que operam na lógica do exemplo a ser repetido, seguido ou almejado e variações binárias, disso.

Com o apoio das ideias de Foucault (2016a, p. 54), ressalto que "a desvalorização é um instrumento de saber e que se não sacudimos a ordem habitual das hierarquias de valores, os segredos do saber jamais de desvelam". Nesse sentido, quando no início do doutorado voltava atenção para a dicotomia presente entre professor e artista ou licenciatura e bacharelado em artes visuais, esbarrava no desvalor difundido a tudo o compreende a educação escolar, em oposição ao glamour do que é narrado a partir da arte instituída. Foi necessário identificar e, depois, eliminar a suposição moral presente nesse raciocínio ainda muito vivo nos ambientes universitários.

Considero que na atualidade, vide as medidas de governo que enfraquecem ainda mais a já deficitária educação pública e as agressões dirigidas às artes, museus e artistas por meio de denúncias totalmente desconectadas do saber 
artístico e educativo ${ }^{5}$, estão em circulação lógicas morais bastante brutas que encontraram condições de existência e disseminação. Carecem das mais elementares noções sobre a função da arte e funcionam sob lógicas utilitaristas (serve o que atende ao modelo econômico), morais (serve o que atende ao modelo considerado padrão e "de bem") e binárias (do par permitido e proibido). Não supomos que, depois da arte garantida na educação básica e de conquistas em direção a alguma justiça social, isso pudesse acontecer.

A formação docente em artes visuais requer que as políticas da arte na licenciatura promovam a distribuição dos lugares da experiência com e sobre a arte. A sua reconfiguração nesse curso, visando que a docência e a educação em artes visuais não apenas repliquem o campo artístico, pode fazer uma ação política que é, por isso, educativa. É preciso trabalhar para, tendo a arte como conhecimento, atitude e experiência, eliminar as distâncias que impedem a formação de comunidades onde sejam aceitas quaisquer existências e saberes, todas as existências e todos saberes. O lugar do agir do licenciado em artes visuais (e todos os demais licenciados) é a escola, que pode vir a ser menos o lugar de conhecimentos destinados previamente pela lógica mercadológica e de vigilância reacionária que se alastra, e mais o lugar de uma educação democrática.

\section{Referências}

AGAMBEN, Giorgio. O Homem sem Conteúdo. Tradução de Cláudio Oliveira. Belo Horizonte: Autêntica Editora, 2012.

A Comunidade que vem. Tradução de Cláudio Oliveira. Belo Horizonte: Autêntica Editora, 2013.

ARDENNE, Paul. Un arte contextual. Creación artística em medio urbano, em situación, de intervención, de participación. Murcia: CENDEAC, 2006.

\footnotetext{
${ }^{5}$ Em referência ao fechamento de exposições como a Queermuseu, em Porto Alegre, em setembro de 2017, acusada de incentivar ofensas religiosas e perversões sexuais, e ao movimento Escola Sem Partido que ataca a liberdade de expressão necessária para a educação democrática. Ambas ocorrências desviam para moralidades as questões de base, arte e educação.
}

Criar Educação, Criciúma, v. 7, №1, jan/jul 2018.- PPGE - UNESC 
ARMAZÉM DE HISTÓRIAS AMBULANTES. Disponível em:

<http://www.historiasambulantes.com.br/>. Acesso em 10 jun. 2017.

BALDISSEROTTO, Ana Flávia. Ana Flávia Baldisserotto: com uma carrocinha, comprando e vendendo histórias anônimas. Entrevista concedida à Barbara Nickel. Documento Eletrônico. 2016. Disponível em:

$<$ http://www.coisasqueagentecria.com/ana-flavia-baldisserotto-com-uma-carrocinhacomprando-e-vendendo-historias-anonimas/>.

CAPRA, Carmen Lúcia. Conhecer, conectar-se, produzir: diferentes vínculos entre a docência em artes visuais e a arte. In: Seminário Nacional Formação Pedagógica e Pensamento Nômade: experimentações curriculares, I, Lajeado, RS. Lajeado: Ed. da Univates, 2015a. P. 206-212. Disponível em: <https://www.univates.br/editoraunivates/media/publicacoes/125/pdf_125.pdf>. Acesso em 25 jun. 2017.

. Ditos sobre professor-artista. Reunião Científica Regional da

ANPED, XI, Curitiba, PR. Educação, movimentos sociais e políticas governamentais, 2016. P. 1-15. Disponível em <http://www.anpedsul2016.ufpr.br/trabalhos-completoseixo-6-formacao-de-professores/>. Acesso em 25 jun. 2017.

; MOMOLI, Daniel Bruno; LOPONTE, Luciana Gruppelli. Para pensar o horizonte da arte e da educação na contemporaneidade. Revista GEARTE, v. 3, n. 2, ago. 2016. Disponível em:

<http://seer.ufrgs.br/index.php/gearte/article/view/65911>. Acesso em: 18 jun. 2017.

CHARRÉU, Leonardo Verde; OLIVEIRA, Marilda Oliveira de. Contribuições da Perspectiva Metodológica "Investigação Baseada nas Artes" e da A/r/tografia para as Pesquisas em Educação. Educ. Rev., Belo Horizonte, v. 32, n. 1, p. 365-382, mar. 2016. Disponível em: <http://www.scielo.br/scielo.php?script=sci_arttext\&pid=S010246982016000100365\&lng=en\&nrm=iso >. Acesso em 10 maio 2017.

CURATORIA FORENSE - LATINOAMÉRICA. Chile, 2017. Disponível em: <http://www.curatoriaforense.net/niued/>. Acesso em: 22 out. 2017.

DALCOL, Francisco. Residência artística e modos de atuação em rede: a viagem como estratégia investigativa. Encontro da Associação Nacional de

Pesquisadores em Artes Plásticas, 24ํㅡ, Santa Maria, RS, 2015. Universidade Federal de Santa Maria, PPGART; Universidade Federal do Rio Grande do Sul, PPGAV, 2015. Disponível em:

<http://anpap.org.br/anais/2015/simposios/s7/francisco_dalcol.pdf>. Acesso em: 25 jun. 2017.

DIAS, Belidson; IRWIN, Rita L. (Orgs.). Pesquisa Educacional Baseada em Arte: a/r/tografia. Santa Maria: Editora da UFSM, 2013. 
DE CARO, Marina (Org.). Micropolis experimentais: traduções da arte para a educação. Tradução de Jane Brodie, Nicholas Rands. Porto Alegre: Fundação Bienal do Mercosul, 2009.

EGAS, Olga Maria Botelho. Metodologias Artísticas de Pesquisa em Educação e Deslocamentos na Formação Docente: a fotografía como construção do pensamento visual. São Paulo: Universidade Presbiteriana Mackenzie, 2017. 146 f. Tese. Programa de Pós-Graduação em Educação, arte e História da Cultura da Universidade Presbiteriana Mackenzie. 2017.

EISNER, Elliot W. Mirar Hacia Adelante: preparar investigadores cualitativos. In:

El Ojo llustrado: indagación cualitativa y mejora de la práctica educativa. Tradução de David Cifuentes e Laura López. Barcelona: Paidós, 1998. p. 263-284.

FOUCAULT, Michel. A Ordem do Discurso. Aula inaugural no Collége de France, pronunciada em 2 de dezembro de 1970. Tradução: Laura Fraga de Almeida Sampaio. São Paulo: Loyola, 1996.

Polêmica, política e problematizações. In: Ditos e Escritos, Volume V: ética, sexualidade, política. Organização, seleção de textos e revisão técnica de Manoel Barros da Motta; Tradução de Elisa Monteiro, Inês Autran Dourado Barbosa. Rio de Janeiro: Forense Universitária, 2014b. P. 219-227.

Editora, 2016a.

O Belo Perigo. Tradução de Fernando Scheibe. Belo Horizonte: Autêntica

GIVEN, Lisa. Handbook of the Arts in Qualitative Research: perspectives, methodologies, examples, and issues. Thousand Oaks, California, EUA: Sage Publications, 2008.

LARROSA, Jorge. Tremores: escritos sobre experiência. Tradução de Cristina Antunes, João Wanderley Geraldi. Belo Horizonte: Autêntica, 2014.

MARQUEZ, Renata. Residências, corresidências e poleiros. In: FONSECA, Carolina. (Org.). Topografia Aérea: uma fábula sobre poleiros e artistas. Belo Horizonte: Instituto Cidades Criativas, 2013.

MASSCHELEIN, Jan; SIMONS, Maarten. Em Defesa da Escola: uma questão pública. Belo Horizonte: Autêntica Editora, 2014a.

Editora, $\overline{2014 b .}$

A Pedagogia, a democracia, a escola. Belo Horizonte: Autêntica

MATADERO MADRID. Disponível em: <http://www.mataderomadrid.org/>. Acesso em: 22 out. 2017. 
MESCHONNIC, Henri. Manifesto em Defesa do Ritmo. Tradução de Cícero Oliveira. Belo Horizonte: Chão de Feira. Caderno de Leituras, n. 40, 2015. Disponível em $<$ http://chaodafeira.com/cadernos/cad40/>.

MORAES, Marcos Jose Santos de. Residência Artística: ambientes de formação, criação e difusão. São Paulo: Faculdade de Arquitetura e Urbanismo da Universidade de São Paulo, 2009. 151 f. Tese de Doutorado. Faculdade de Arquitetura e Urbanismo da Universidade de São Paulo, São Paulo. 2009. Disponível em <http://www.teses.usp.br/teses/disponiveis/16/16136/tde-29042010093532/pt-br.php>. Acesso em 25 jun. 2017.

OLIVEIRA, Marilda. Contribuições da Perspectiva Metodológica 'Investigação Baseada nas artes' e da A/r/tografia para as Pesquisas em Educação. 36 ${ }^{a}$ Reunião Anual da ANPED, GT 24 - Educação e Arte. 2013. Disponível em: $<$ http://36reuniao.anped.org.br/pdfs_trabalhos_aprovados/gt24_trabalhos_pdfs/gt24_ 2792_texto.pdf>. Acesso em: 19 ago. 2014.

PEREC, Georges. Tentativa de esgotamento de um local parisiense. Tradução de Ivo Barroso. São Paulo: Gusstavo Gili, 2016.

Aproximações do quê? Alea, Rio de Janeiro, v. 12, n. 1, p. 177-180, Jun, 2010 . Disponível em <http://www.scielo.br/scielo.php?script=sci_arttext\&pid=S1517106X2010000100014\&lng=en\&nrm=iso >. Acesso em 20 mar. 2017.

RANCIÈRE, Jacques. A Partilha do Sensível: estética e política. São Paulo: EXO experimental; Editora 34, 2009.

O Mestre Ignorante: cinco lições sobre a emancipação intelectual.

Tradução de Lílian do Vale. Belo Horizonte: Autêntica, 2011a.

O Espectador Emancipado. Tradução de Ivone C. Benedetti. São Paulo: Editora WMF Martins Fontes, 2012.

ROCKHILL, Glossário. In: RANCIÈRE, Jacques. Estética e Política. A partilha do sensível. Tradução de Vanessa Brito. Porto: Dafne Editora, 2010.

SKLIAR, Carlos. Desobedecer a Linguagem. Belo Horizonte: Autêntica, 2014.

VASCONCELLOS, Sônia Tramujas. Entre \{Dobras\} Lugares da Pesquisa na Formação de Professores de Artes Visuais e as Contribuições da Pesquisa Baseada em Arte na Educação para ampliação de relações entre Representação Visual e Produção de (Auto)Conhecimento. Curitiba: Universidade Federal do Paraná, 2015. 215 f. Tese. Programa de Pós-Graduação em Educação da Universidade Federal do Paraná. 2015. 
VILLAMIZAR, Guillermo. Miwon Kwon, cuestionario sobre lo contemporáneo. 2012. Documento sonoro. Disponível em: <http://esferapublica.org/nfblog/miwonkwon-cuestionario-sobre-lo-contemporaneo/>. Acesso em: 08 maio 2017.

Recebido em outubro 2017 Aprovado em fevereiro 2018

Criar Educação, Criciúma, v. 7, nº1, jan/jul 2018.- PPGE - UNESC 